Table 2. ESCAPE OF PROTHIN FROM RAT LENS OF DIFFERENT AGES INTO DISTILLED WATER

$\begin{array}{cccc}\begin{array}{c}\text { Weight lens } \\ \text { mg }\end{array} & \mu \mathrm{g} / \text { lens } & \begin{array}{c}\text { Protein diffused into medium } \\ \mu \mathrm{g} / \mathrm{mg} \text { wet weight } \\ \text { (normal lens) }\end{array} & \begin{array}{c}\mu \mathrm{g} / \mathrm{mg} \text { dry weight } \\ \text { (swollen lens) }\end{array} \\ 23(2) & 1,580 & 69 & \\ 19(3) & 1,140 & 60 & 194 \\ 20(20) & 890 & 44 & \\ 22(2) & 1,200 & 54 & 266 \\ 21(3) & 1,090 & 52 & 46 \\ 45(4) & 820 & 18 & 63 \\ 44(4) & 1,050 & 24 & \end{array}$

Conditions are as described in Table 1. The numbers in parentheses are the numbers of lenses. Protein was estimated by the biuret method of liobinson and Hogden ${ }^{6}$.

Sippel ${ }^{4}$ examined the protein content of the lens in young galactose-fed rats and found that it decreased at about the time that the dense nuclear opacity appeared. This decrease coincided with appearance of protein in the fluids of the eye, probably indicating an increase in permeability of lens fibre membranes and capsule which are normally almost impermeable to lens proteins. Table 2 shows that protein eseapes from lenses immersed in distilled water and that this is greater from the young than from the mature lens. The dry weight of the swollen lens is almost entirely protein and the loss from the young lens represents about 20 per cent and that from the mature lens about 5 per cent of the total protein. It is possible that the loss of protein is connected with formation of dense nuclear opacity in the young lens. Waley ${ }^{5}$ noted that a macerated lens remained transparent but that addition of fluid caused turbidity to develop. Charlton and van Heyningen? have evidence that proteins of small molecular size may have been lost from the senile cataractous lens by leakage.

In swelling, in opacity formation and in capsular permeability the behaviour of the young and of the mature lens exposed to distilled water parallels the behaviour in vivo of the lenses of young and mature galactose-fed rats. It seems probable that the cause of the difference is the same in both cases and the simplest explanation of the difference in swelling is that the capsule and fibre membranes of the young lens are more elastic and more permeable than those of the mature lens. It is generally agreed that the human lens becomes less elastic with age as presbyopia develops.

Nuffield Laboratory of Ophthalmology,

A. PIRIe

University of Oxford.

Received August 7; revised September 22, 1967.

${ }^{2}$ van Heyningen, R., Nature, 184, 194 (1959).

2 Kinoshita, J. H., Invest. Ophthal., 5, 786 (1966).

3 Patterson, J. W., and Bunting, K. W., Docum. Ophthal., 20, 64 (1966).

4 Sippel, T. O., Invest. Ophthal., 5, 570 (1966).

${ }^{3}$ Waley, S. G., Exp. Eye Res., 4, 293 (1965).

- Robinson, H. W., and Hogden, C. G., J. Biol. Chem., 135, 707 (1940).

: Charlton, J. M., and van Heyningen, R., Exp. Eye Res. (1968).

\section{Incorporation of Sulphur-35 into the Subcommissural Organ and Reissner's Fibre}

THE subcommissural organ $(S C O)$ is a specialized area of the ependymal border below the commissura posterior and it occurs in the brain of all vertebrates. In most species the products of apical secretion from the $S C O$ may pass, as does Reissner's fibre, through the ventricles of the brain and the central canal to the posterior end of the spinal cord $^{1,2}$. The function of the SCO is not yet known.

Histoautoradiographic investigations after the injection of ${ }^{35} \mathrm{~S}$-cystine $(1.2-4.8 \mu \mathrm{c} . /$ body weight, partly repeated) have shown that ${ }^{35} \mathrm{~S}$-incorporation of sulphur-35 into the $S C O$ and Reissner's fibre in the carp (Cyprinus carpio L.) is greater than in most other organs (Figs, 1 and 2).
Table 1. RkLATIVE CONCENTRATIONS OF SUIPHUR-35 IN THE BRAIN AND OTHER ORGANS OF CARP AFTER SEVERAL INCUBATION PERIODS Time of Injected ac-

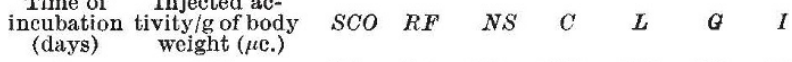

$\begin{array}{rllllllll}2 & 4 \cdot 75 & 5 \cdot 5 & 6 \cdot 4 & 3 \cdot 4 & 2 \cdot 2 & 4 \cdot 0 & 6 \cdot 8 & 8 \cdot 3 \\ 14 & 4 \times 2 \cdot 5 & 2 \cdot 6 & 5 \cdot 7 & 2 \cdot 3 & 2 \cdot 0 & & & \end{array}$

$R F$, Reissner's fibre; $N S$, neurosecretory areas in the brain ; $C$, cerebellum $L$, liver: $G$, goblet cells of the midgut; $I, \beta$ cells in the islets of Langerhans.

The relative concentrations of sulphur-35 in the different tissues were determined photometrically ('Table 1) and the only structures with a greater cystine content than the $S C O$ and Reissner's fibre were the goblet cells of the midgut and the islets of Langerhans. When the spinal cords of carp (weight, 530-750 g; brain and spinal cord, 15-20 $\mathrm{cm})$ were fixed and investigated autcradiographically several days after the injections of sulphur-35 the activity in Reissner's fibre was found to have moved daily 2-3 per cent of its total length, giving an absolute measurement of about $0.5 \mathrm{~cm} /$ day. Thus it takes about 40 days for substances from the fibre to pass through the central canal of the spinal cord.

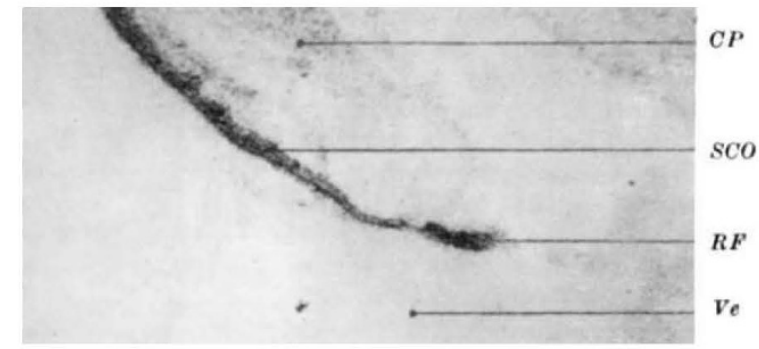

Fig. 1. Autoradiograph of unstained longitudinal section through the $S C O$ and Reissner's fibre. $(\times 50) C$.$P , Commissura posterior: S C O$,

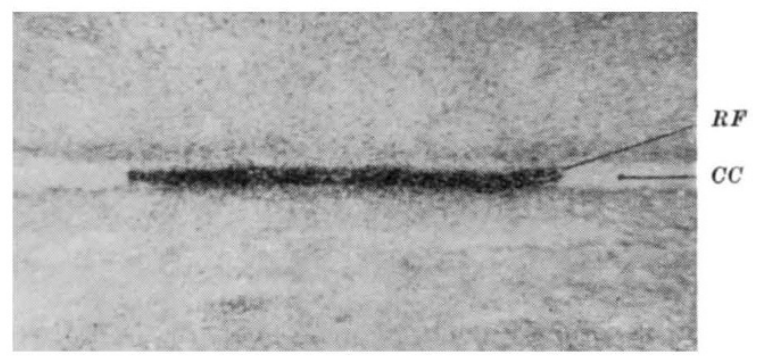

Fig. 2. Autoradiograph of a longiturlinal section through the spinal cord with the central duct and Reissner's fibre. $(\times 50) R$.$F , Reissner's$ fibre; $C C$, central canal.

These results show that there is intensive metabolism of sulphur containing substances in the $S C O$, and these must include the complex mucopolysaccharide-protein which has been demonstrated in Reissner's fibre system ${ }^{2-4}$.
G. Sterba
A. Ermisch
K. Freyer
G. HartimanN

Zoologisches Institut,

Karl-Marx-Universität,

Leipzig.

Received July 12; revised August 23, 1967.

1 Oksehe, A., Z. Zellforseh., 57, 240 (1962).

${ }^{2}$ Sterba, G., Verh. Deutsch. Zool. Ges., 393 (1966).

${ }^{3}$ Sterba, G., and Naumann, W., Z. Zellforsch., 72, 516 (1966).

- Sterba, G., Müller, H., and Naumann, W., Z. Zellforsch., '76, 355 (1967). 